„Analiza i Egzystencja” 45 (2019)

ISSN 1734-9923

DOI: $10.18276 /$ aie.2019.45-03

\title{
MIROSŁAW RUTKOWSKI
}

\section{KRZYWDZENIE A PRZYZWALANIE NA KRZYWDE. CZĘŚĆ II: PRAWO DO SAMOOBRONY}

Słowa kluczowe: krzywdzenie, przyzwolenie na krzywdę, Maszyna Tooleya, zasada moralnej symetrii, kontrfaktyczna definicja krzywdy, postronny obserwator, prawo do samoobrony

Keywords: hurting, allowing harm, Tooley's machine, the principle of moral symmetry, third party, counterfactual definition of harm, third party observer, right to self-defense

Pewne znaczenie dla ustalenia wzajemnej wartości krzywdzenia i przyzwalania na krzywdę może mieć odpowiedź na pytania, jakie mogłyby być zalecenia moralne dla znajdujących się w Maszynie Tooleya dzieci w sytuacji, gdyby potrafiły one pokierować swoim losem w taki sposób, że miałyby wpływ na zaistnienie osoby podejmującej niekorzystną dla nich decyzję. Wiemy, że jeśli jakaś osoba wciśnie guzik, zainicjuje w ten sposób proces prowadzący do krzywdy pierwszego dziecka, a to znaczy, iż

* Mirosław Rutkowski - profesor US, kierownik Zakładu Etyki w Instytucie Filozofii Uniwersytetu Szczecińskiego. Prace naukowe z zakresu metaetyki, etyki normatywnej oraz etyki praktycznej.

Address for correspondence: Mirosław Rutkowski, University of Szczecin, Faculty of Philosophy, Krakowska 71-79, 71-017 Szczecin. E-mail: rutkowski1957@gmail.com. 
prawdziwe w tym przypadku byłoby powiedzenie, że dziecko nie zostałoby skrzywdzone, gdyby osoba ta nie istniała. Jeśli inna osoba zachowa się natomiast w sposób diametralnie odmienny, tj. powstrzyma się od wciśnięcia guzika, oznaczać to będzie, że jakiś istniejący już ciąg zdarzeń doprowadzi do krzywdy drugiego dziecka i prawdziwe stanie się z kolei twierdzenie, które jest w jakimś sensie sprzeczne z pierwszym, a mianowicie, że dziecko dozna krzywdy nawet wtedy, gdyby ta osoba nigdy nie istniała. Czy jeśli założymy, że każde z tych dzieci mogłoby zapobiec istnieniu takiej osoby, to uczynienie tego miałoby taką sama wartość w jednym i drugim przypadku? Czy z etycznego punktu widzenia istnieją takie same racje za wykonaniem czynności uniemożliwiającej zaistnienie jakiejś osoby zarówno w jednej, jak i w drugiej sytuacji? Nie sądzę, aby można było wskazać uzasadnione powody dla tak daleko idącej równoważności sądów moralnych (Kamm, 2007, s. 17-18). Ktoś, kto z rozmysłem uniemożliwiłby zaistnienie żyjącej osoby po to, aby zapobiec własnej krzywdzie, cieszyłby się z pewnością większą przychylnością moralną, aniżeli ten, kto dokonałby tego bez istotnego powodu. Dzieje się tak zarówno w sytuacji, w której uznajemy, że uniemożliwienie czyjegoś zaistnienia jest całkowicie zrozumiałe z uwagi na negatywne konsekwencje, jakie innej osobie przyniosłoby jego istnienie, jak i wówczas, gdy konsekwencje te nie uzasadniają w pełni tego typu postępowania. Spowodowanie, że żyjąca osoba nie mogłaby zaistnieć, jest $\mathrm{w}$ ramach takiego porównania lepsze nie tylko wtedy, gdy z moralnego punktu widzenia stanowi całkowicie usprawiedliwiony i jedyny sposób postępowania, w jaki możemy uchronić się od krzywdy, ale również wtedy, gdy nie ma tak jednoznacznego uzasadnienia moralnego, tj. nawet jeśli jest prawdą, że rozmiar doznanej z tego powodu krzywdy nie rekompensuje w pełni zła, jakie wnosi ze sobą działanie tego, kto w ten sposób pragnie się przed nią obronić.

Przeciwko zasadzie moralnej symetrii bardziej bezpośrednio i znacząco, aniżeli te wyimaginowane przykłady, przemawiać może taki oto fakt, że dzieciom nie przysługuje równe prawo do samoobrony w chwili zagrożenia. Jeżeli nawet założylibyśmy, że każde z nich dysponuje zbliżoną możliwością zapobieżenia własnej krzywdzie w ten sposób, że stosując określone środki przemocy, potrafiłoby jakoś zmusić zagrażającą jej potencjalnie osobę do zaniechania działań pod jego adresem i przeniesienia krzywdy na drugie dziecko, nie moglibyśmy na tej podstawie dowodzić, iż każde z nich może w tym celu stosować takie same metody represji i narażać innych ludzi 
na porównywalne szkody (Kamm, 1996, s. 77-78, 102-103). W pewnym sensie zarówno wciśnięcie guzika, jak i powstrzymanie się od takiego zachowania stwarzają podobne zagrożenie dla zdrowia dzieci, co powoduje, że każde z nich może być słusznie uznane za niewinna ofiarę. Ponieważ prawdą jest także to, że sprawca czynności wywołuje niebezpieczeństwo doznania krzywdy za sprawa własnego postęowania w odniesieniu do obu dzieci, wielu z nas może na tej podstawie dojść do wniosku, że fakt ten w pełni wystarcza do tego, aby można było uzasadnić nie tylko podjęcie działań mających na celu obronę własną, ale także i to, że każde dziecko ma prawo przedsięwziąć przeciwko niemu takie same środki zapobiegawcze (Montague, 1981, s. 209-217; McMahan, 2012, s. 515-517; Rutkowski, 2017, s. 179-182). Przyjęcie tak daleko idących uprawnień do zadawania krzywdy w ramach obrony własnej, choć zapewne możliwe do zaaprobowania z punktu widzenia intuicji posiadanych przez ofiary, może niekiedy stanowić moralne nadużycie. Dlaczego tak jest? Głównie z tego powodu, że osobie, która postanawia wcisnąć guzik, przynależy inny status moralny - a co za tym idzie i odmienny zakres ochrony - od tego, jaki miałaby ona wówczas, gdyby zdecydowała, że tego nie zrobi. Wciskając guzik osoba ta jest świadoma, że w ten sposób inicjuje sekwencję zdarzeń prowadzącą do krzywdy dziecka, a także zdaje sobie sprawę, że wykonanie tego rodzaju czynności stwarza poważne zagrożenie dla życia, jakie chciałoby ono prowadzić; dlatego też to, co czyni, sprawia, że z moralnego punktu widzenia staje się napastnikiem. Inaczej sprawy będą wyglądać, gdy nie wciśnie guzika, przyzwalając tym samym na wyrządzenie podobnej szkody jakiemuś innemu dziecku. W takim wypadku fakty są następujące: osoba ta nie miała żadnego wpływu na zaistnienie procesu, który prowadzi do krzywdy dziecka, niemniej jednak prawdą jest, że może go zatrzymać i zapobiec nieszczęściu. Gdy warunki te zachodzą, nie sposób sensownie powiedzieć, że napastnikiem może być również osoba, która decyduje się nie wcisnąć guzika. Dzieje się tak między innymi dlatego, że nie jest ona przyczynowo uwikłana w powstanie sekwencji zdarzeń, która prowadzi do czyjejś krzywdy. Ponieważ prawdziwe jest twierdzenie, że pomimo, iż osoba ta mogła do niej nie dopuścić, jednak ostatecznie tego nie uczyniła, to z tego względu rzeczą słuszną wydaje się być uznanie moralnego z istoty rzeczy założenia, że posiada ona odrębny status niedoszłego wybawcy, a więc kogoś, kto ostatecznie nie skorzystał z możliwości zapobieżenia czyjejś krzywdzie w sytuacji, gdy nie miał takiego obowiązku (o tym, że nie ma obowiązku 
zapobiegania w ten sposób krzywdzie, pisałem obszernie w innym miejscu, zob. Rutkowski, 2017, s. 129-185).

W większości przypadków, w których czyjeś zachowanie może sprawić, że bez istotnego powodu skrzywdzony zostanie ktoś inny, moralność dozwala, aby pod adresem domniemanego sprawcy można było zastosować środki opresyjne co najmniej w takim wymiarze, by wyrządzały mu krzywdę nie większą od tej, jaka byłaby udziałem pewnych osób z powodu jego postępowania. Jest to teza na ogół słuszna, kiedy wypowiadamy ją bez doprecyzowania, stosując wysoki stosunkowo poziom uogólnienia. Teraz trzeba jednak dopowiedzieć pewną ważną kwestię, a mianowicie, że choć zgodnie z tym poglądem to za sprawą swego postępowania sprawca może podlegać przemocy, jakiej używa się w obronie własnej, jednakże w istocie rzeczy to nie jego postępowanie samo w sobie czyni go podatnym na wynikające z niej szkody, ale postępowanie nieodłącznie związane z zainicjowaniem sekwencji zdarzeń, która prowadzi do krzywdy niewinnych istot. Wynika z tego, że nie należy w obronie własnej stosować przemocy wobec osoby, która może sprawić, że ktoś inny dozna niezasłużonej krzywdy, jeśli jej zachowanie nie jest powiązane z krzywdą we wskazany sposób. Dzieje się tak, ponieważ względem tej krzywdy osoba ta jest de facto postronnym obserwatorem - choć może spowodować, że jakieś istniejące bez jej udziału zagrożenie zostanie bezpowrotnie anulowane, to jednak sama nikomu w ten sposób nie zagraża ani też nie przyczyniła się do tego, że ktokolwiek został narażony na tego typu zagrożenie wbrew własnej woli.

$Z$ dotychczasowych rozważań wynika, że ochrony moralnej przynależnej postronnemu obserwatorowi nie posiada osoba, która, wciskając guzik, staje się tym samym napastnikiem wobec jednego z dzieci. Oczywiście można byłoby zasugerować, że jest tak dlatego, ponieważ napastnik nie jest postronnym obserwatorem. Teza ta jest zrozumiała sama w sobie i nie wymaga dalszego uzasadnienia, jednak nie stanowi najważniejszej racji, dla której mielibyśmy sądzić, że dziecku przynależy prawo do samoobrony. Wbrew temu, co się niekiedy sądzi, nie jest nią również i to, że w wyniku tego, co zrobi podmiot będący napastnikiem, skrzywdzona zostanie jakaś niewinna istota. O tym, że osoba wciskająca guzik może podlegać szkodzie będącej koniecznym skutkiem obrony własnej poszkodowanego w ten sposób dziecka, świadczy przysługujące każdemu z nas prawo, aby nie zostać przez nikogo skrzywdzonym bez moralnie uzasadnionego powodu i wbrew własnej woli. Prawo to nie zakłada jednakże przyzwolenia na stosowanie 
odwetu wobec sprawcy każdej czynności, która mogłaby mieć ten skutek. Taka formuła byłaby prawdopodobnie zbyt szeroka. Obejmowałaby nie tylko zgodę na zadawanie krzywdy w samoobronie z powodu zagrożenia będącego koniecznym następstwem jakiegoś przypadku lub obiektywnej konieczności - co oznaczałoby, że przemoc można by stosować wobec tych, którzy nie mogli zapobiec własnym czynom prowadzącym do krzywdy, nawet jeśli postępowali w ten sposób wbrew swojej woli - ale także z powodu trudnej czasami do wyeliminowania niewiedzy, że niewykonanie pewnych czynności umożliwia powstanie lub kontynuację obiektywnie istniejących sekwencji zdarzeń, które w odniesieniu do pewnych - nawet nieznanych nam - osób również mogą prowadzić do takiego celu. W okolicznościach generowanych przez Maszyne Tooleya należałoby skłaniać się raczej ku osądowi, że tego rodzaju uprawnienie umożliwia zapobieganie własnej krzywdzie jedynie wobec tych, którzy inicjują to zagrożenie lub w jakikolwiek inny sposób przyczyniają się do powstania sytuacji, w której takiemu zagrożeniu ktoś zaczyna podlegać.

To oznacza, że dziecko, które dozna szkody na skutek czynności polegającej na tym, że odmawia się wciśnięcia guzika, nie ma prawa do stosowania takich samych metod w celu zwiększenia własnego bezpieczeństwa. Osoba, która po namyśle decyduje się przyzwolić na jego krzywdę, staje się przez to bowiem niedoszlym wybawcą. Nie będąc w najmniejszym stopniu uwikłana przyczynowo w zapoczątkowanie sytuacji zagrożenia krzywdą któregokolwiek z dzieci, posiada ona - jak każdy tego typu niedoszły wybawca - status osoby postronnej, co, z moralnego punktu widzenia, czyni ją całkowicie niepodatną na tę formę przemocy, jaką dzieci mogłyby zastosować w obronie własnej.

W tym miejscu przeciwnicy moralnego rozróżnienia między krzywdzeniem a przyzwalaniem na krzywdę mogliby zauważyć, że status niewinnej ofiary, jaki z pewnością przynależy dziecku narażonemu na krzywdę z powodu niewciśnięcia guzika, nie daje mu w żadnym razie mniejszego prawa, aby nie zostać skrzywdzonym, od tego, które przypisuję niedoszłemu wybawcy - oboje sq osobami postronnymi i na tej podstawie obojgu im przynależy podobna ochrona moralna. Nie wiadomo więc na jakiej podstawie zakładam, że osoba stojąca wobec wyzwań, jakie pod jej adresem kieruje Maszyna Tooleya, ma prawo nie wcisnąć guzika i doprowadzić w ten sposób do krzywdy dziecka, natomiast dziecko nie ma takiego samego prawa zadać podobnej krzywdy tej osobie w akcie samoobrony. Otóż wydaje się, że jest 
pewien istotny powód po temu, aby tak właśnie twierdzić. Na ogół zgadzam się, że w normalnej sytuacji zwykle jest tak, że wyrządzenie porównywalnej krzywdy osobom postronnym jest z moralnego punktu widzenia równie złe bądź niewłaściwe. Istnieją jednak pewne okoliczności, w których zasada ta nie obowiązuje w tak mocnym sensie (Parfit, 2012, s. 429). Mają one miejsce wtedy, kiedy występuje zjawisko obiektywnego zdeterminowania, tj. wówczas, gdy prawdą jest, że nawet jeśli kogoś nie skrzywdzimy, ten ktoś i tak dozna podobnej krzywdy, z tą tylko różnicą, że dokona się to w inny sposób. Kiedy zachodzi taka sytuacja - co ma miejsce w przypadku dziecka, które jest częścią sekwencji zdarzeń prowadzącej do jego kalectwa - to wiemy, że gdybyśmy sami skrzywdzili tę osobę, nie skutkowałoby to tym, że z powodu naszego postępowania wydarzyłaby się rzecz gorsza od tej, jaka miałaby nieuchronnie miejsce również wtedy, gdybyśmy tak nie postąpili. Dla zwolenników bezwzględnego charakteru wartości moralnych oznaczałoby to również, że osoba ta nie znalazłaby się w gorszej sytuacji od tej, w jakiej byłaby wówczas, gdybyśmy postąpili inaczej. W tego typu przypadkach, nawet jeśli w jakimś znaczeniu słuszne byłoby powiedzenie, że jednak krzywdzimy kogoś, to za słuszne należałoby uważać także i to, że nie krzywdzimy go w takim samym stopniu, jak wówczas, kiedy krzywdzimy kogoś wtedy, gdy bez naszego udziału jego krzywda w ogóle nie miałaby miejsca. Aprobata takiego punktu widzenia zazwyczaj pociąga za sobą zgodę co do tego, że w warunkach obiektywnego zdeterminowania powodowanie czyjejś krzywdy staje się moralnie mniej istotne.

A czy dałoby się pójść o krok dalej i powiedzieć, że zjawisko obiektywnego zdeterminowania w ogóle wyklucza możliwość krzywdzenia? Do takiego wniosku mogłaby na przykład skłaniać jedna ze sformułowanych przez Joela Feinberga koncepcji krzywdy, której istota polega na tym, że skrzywdzenie możliwe jest dopiero po zaistnieniu pewnego kontrfaktycznego warunku. Otóż Feinberg uważa, że w niektórych wypadkach tylko wtedy możemy mówić, że jedna osoba krzywdzi drugą, gdy w wyniku tego, co ona czyni, ofiara znajdzie się w gorszej sytuacji od tej, w jakiej znajdowałaby się wówczas, gdyby sprawca tak się nie zachował (Feinberg, 1987, s. 33-34). Zastosowanie rozumianego w takim znaczeniu pojęcia ,wyrządzenia krzywdy" w odniesieniu do okoliczności, w których istnieje stosunkowo duże prawdopodobieństwo obiektywnego zdeterminowania, rodzi poważne następstwa dla moralnej oceny działań naruszających czyjeś interesy. Zgodnie 
z tym poglądem ci, którzy podważają możliwość wyrządzania komukolwiek krzywdy w takiej sytuacji, rozumowaliby w następujący sposób:

P1: Aby postępowanie jednej osoby mogło wyrządzić krzywdę drugiej, musi spowodować, że druga osoba znajdzie się w gorszej sytuacji od tej, w jakiej byłaby, gdyby pierwsza z nich tak nie postąpiła.

P2: Znalezienie się w gorszej sytuacji zakłada zatem relację między dwoma stanami, w jakich znajdowałaby się ta osoba.

P3: Aby ktoś mógł znaleźć się $\mathrm{w}$ gorszej sytuacji w jednym $\mathrm{z}$ tych stanów, stan alternatywny, z którym jest on porównywany, musi być takim stanem, w którym byłby on w lepszej sytuacji.

P4: Ponieważ występowanie zjawiska obiektywnego zdeterminowania powoduje, że stan, w którym znalazłaby się druga osoba - gdyby pierwsza z nich nie postąpiła tak, jak faktycznie postąpiła - nie jest stanem, w którym byłaby w lepszej sytuacji, to również stan, w którym znalazłaby się, gdyby pierwsza osoba postąpiła z kolei tak, jak postąpiła, nie jest stanem, w którym byłaby w gorszej sytuacji.

W: Tak więc, w tym wypadku postępowanie jednej osoby nie może wyrządzić krzywdy drugiej z nich.

W świetle tego poglądu za prawdziwe można byłoby uznać twierdzenie, że gdybyśmy zdecydowali się ostatecznie nie wcisnąć guzika, ciało jednego z dzieci zostanie tak zdeformowane i uszkodzone, iż do końca życia pozostanie ono kaleką, niemniej jednak nie można na tej podstawie sądzić, że to my wyrządziliśmy mu taką krzywdę z powodu tego, co zrobiliśmy. Nie zamierzam rozważać tu wszystkich aspektów tej propozycji, a szczególnie różnicy, jaką z tego punktu widzenia daje się zaobserwować między wyrządzaniem krzywdy (i wynikającą z tego kwestią odpowiedzialności za własne czyny), a samym jej istnieniem. (Większość publikacji omawiających tego typu porównawczą koncepcję krzywdy traktuje warunek kontrfaktyczności jako kryterium zaistnienia krzywdy. Wydaje się, że taki cel stawiał sobie również Feinberg, gdy formułował ją w Harm to Others. Niektórzy jednak kontrfaktyczności przypisują [zazwyczaj nieświadomie] podwójne znaczenie: raz traktują to jako warunek istnienia krzywdy [lub jako warunek jej doświadczenia], innym razem jako warunek jej wyrządzenia. Robią tak m.in.: Benatar, 2009, s. 20-21 i Różyńska, 2013, s. 50-66). Chciałbym poruszyć jedynie zagadnienie dotyczące pewnych skutków, które z takiej czynności wynikają zarówno dla ofiary, jak i jej sprawcy. Idzie o to, czy w sytuacji, w której występuje obiektywne zdeterminowanie, wykonanie działania 
określanego tu mianem przyzwolenia na krzywdę może oznaczać, że ten, kto tak postępuje, faktycznie kogoś krzywdzi. Ci, którzy są zwolennikami zaprezentowanego powyżej argumentu, gdyż zakładają konieczność zastosowania - wyrażonego w P1 - warunku kontrfaktyczności, będą temu zdecydowanie przeciwni. Nie jest to jednak racja rozstrzygająca. Do rozważenia pozostaje jeszcze kwestia, która, jak sądzę, ma dużo bardziej obiektywny i uniwersalny charakter, a mianowicie, czy odwoływanie się do warunku kontrfaktyczności jest w tych okolicznościach rzeczywiście niezbędne. Tutaj odpowiedź nie jest już taka oczywista. Choć tego rodzaju porównawcza koncepcja krzywdy może wydawać się dość przekonująca i może nadzwyczaj dobrze współgrać z naszymi intuicjami w tym względzie, nie dowodzi to jednakże w sposób jednoznaczny, że nie ma możliwości, abym swoim postępowaniem skrzywdził kogoś, kto nie znalazłby się w gorszej sytuacji od tej, w jakiej byłby, gdybym tak nie postąpił. (O tym, że można wyrządzić komuś krzywdę nawet wtedy, gdy warunek kontrfaktyczności pozostaje niespełniony, przekonani są: Parfit, 2012, s. 556-560; Harman, 2009, s. 137-154; Steinbock, 2009, s. 155-178; Cohen, 1997, s. 27-40; Harris, 1992, s. 88-92; Morreim, 1988, s. 3-33; Feinberg, 1992, s. 3-36). A to oznacza, że nie jest do końca jasne, w jakim stopniu można uważać zasadę kontrfaktyczności za konieczny warunek wyrządzenia krzywdy. Ponieważ nie dokonuję w tym względzie ostatecznych ustaleń - a szczególnie takich, które dla stwierdzenia krzywdy wymagałyby przeprowadzenia czynności porównywania zgodnie z zasadami wyrażonymi w pierwszych trzech przesłankach - rzeczą nierozsądną byłoby w takim wypadku akceptować tezę, że w sytuacji obiektywnego zdeterminowania wyrządzenie krzywdy jest niemożliwe. Roztropność podpowiada, że należałoby przyjąć daleko bardziej umiarkowane stanowisko, zgodnie z którym szkody, jakie nasze zachowanie wyrządza innym w sytuacji obiektywnego zdeterminowania, nie mają prawdopodobnie takiej doniosłości moralnej jak te, które czynimy wówczas, gdy ich wystąpienie uzależnione jest wyłącznie od tego co sami zrobimy.

Uwagi te nie prowadzą bezpośrednio do wniosku, że nie może być żadnej obiekcji moralnej w odniesieniu do postępowania niedoszłego wybawcy. Wiemy bowiem, że gdyby osoba, która nim jest, zachowała się inaczej, to dziecko, które z powodu tego postępowania jest kaleką, byłoby w pełni zdrowe. Uzasadniają one w pewnym sensie twierdzenie, że w tych warunkach zapewne lepiej jest, gdy ktoś krzywdzi osobę, która i tak zostałaby skrzywdzona w ten sposób, niż taką, która nie zostałaby w ogóle 
skrzywdzona, gdyby sam jej nie skrzywdził. Tak jest również w odniesieniu do analizowanego przypadku. Ponieważ postępowanie, które przyzwala na krzywdę dziecka nie inicjuje zdarzeń, które prowadzą do jego krzywdy i nie powoduje, że dziecko z powodu tego postępowania znajdzie się w gorszej sytuacji, natomiast postępowanie polegające na krzywdzeniu daje początek zdarzeniom prowadzącym do krzywdy oraz powoduje, że objęte nim dziecko znajdzie się w gorszej sytuacji, to jeśli prawdą jest, że w obu przypadkach mamy do czynienia $z$ takim samym skutkiem, wówczas słuszne zdaje się być przekonanie, że postępowanie mające tę charakterystyczną własność, iż przyczynia się do tego, że dziecko znajdzie się w gorszej sytuacji, jest moralnie bardziej zdrożne, aniżeli to, które takiej własności nie ma. Trudno mi sobie wyobrazić, aby w takich okolicznościach ktoś, kto rozumie doniosłość wartości moralnych i jest świadomy tej różnicy, był tak samo skłonny wykonać czynność polegającą na skrzywdzeniu dziecka, jak czynność, która jedynie przyzwala na krzywdę - tj. by z równą gorliwością wspierał postępowanie zarówno napastnika, jak i niedoszłego wybawcy.

Gdy w ten sposób uzasadnia się rozróżnienie między krzywdzeniem a przyzwalaniem na krzywdę, wpływa się nie tylko na to, jak daleko wobec innych ludzi mogą posunąć się w swoim postępowaniu osoby zagrożone, ale ustala się również moralną zasadę działania, która dotyczyć może każdego z nas. Wyobraźmy sobie oto, że żadne znajdujące się w Maszynie Tooleya dziecko nie dysponuje środkami, które byłyby moralnie adekwatne do sytuacji, w jakiej się znajduje, oraz wystarczające do tego, aby obronić się przed krzywdą. Czy w takim wypadku zawsze powinno być dozwolone, aby mogła to za nich uczynić każda inna osoba, która dysponowałaby w tym względzie odpowiednimi możliwościami? Bynajmniej. Wolność postępowania na rzecz przeciwdziałania czyjejś krzywdzie nie może mieć nieograniczonego charakteru. Dzieje się tak na przykład wtedy, gdy osoba, która mogłaby doznać szkody z powodu postępowania innych istot, jest przekonana, że z jej własnego punktu widzenia szkoda ta nie tylko nie jest dla niej niczym złym, ale jej istnienie nie jest rzeczą gorszą od jej nieistnienia; bądź też wtedy, gdy z określonych powodów (które nie wydają się istotne dla poruszanego zagadnienia) nie wyraża ona dobrowolnego przyzwolenia na to, aby pod jej adresem taka pomoc została udzielona. Zasady te nie obowiązują wyłącznie w okolicznościach, w których ona sama może zapobiec własnej krzywdzie, ale również wszędzie tam, gdzie nie ma do tego celu wystarczających środków. Pominąwszy tego typu względy, które trudno byłoby zastosować do 
osób nie spełniających warunków potrzebnych do ich uprawomocnienia (co niekiedy dotyczy również i dzieci), sądzę, że w pozostałych przypadkach za słuszne należałoby uznać twierdzenie, iż jeśli jakaś osoba zagrożona krzywdą mogłaby zastosować pewne środki w obronie własnej, to trzeba by przyznać, że wolno byłoby ich użyć w podobnym celu również osobie trzeciej. Pogląd ten opiera się na słusznym skądinąd przekonaniu, że jeśli komukolwiek wolno jest zapobiec własnej krzywdzie poprzez uczynienie tego, co może spowodować dotkliwą szkodę osoby, która do tej krzywdy się przyczynia, to wolno mu - pomijając, oczywiście, wyszczególnione powyżej warunki - zrobić to samo także wówczas, gdy w ten sposób zapobiegnie podobnej szkodzie kogoś innego.

Niektórzy idą jeszcze dalej i uważają, że tego typu ograniczenia nie wynikają z aktów woli, lecz są ugruntowane obiektywnie w tym sensie, że moralne przyzwolenie na zastosowanie opresyjnych środków może odnosić się do każdego zagrożonego krzywdą podmiotu - niemniej jednak wyłącznie do niego (Davis, 1984, s. 180-190). Wynikałoby z tego, że tylko dziecku umieszczonemu w Maszynie Tooleya - i nikomu więcej - wolno byłoby zapobiec swojej krzywdzie, albowiem to ono jest zagrożone. Gdyby tak rzeczywiście było, różnica pomiędzy krzywdzeniem a przyzwoleniem na krzywdę, choć być może miałaby jakieś znaczenie z punktu widzenia obojga dzieci, nie mogłaby być stosowana, nawet z tak nikłym powodzeniem, na skalę uniwersalną. To umacniałoby tezę, że w odniesieniu do większości tego typu przypadków słuszna wydaje się być zasada moralnej symetrii. Czy jest coś, co przemawia za tym, że tak nie jest? Czy zastosowanie w odwecie opresyjnych środków może rzeczywiście zostać usprawiedliwione tym, że pomiędzy zagrożoną osobą a potencjalnym krzywdzicielem istnieje taka specyficzna i bezpośrednia relacja? Odpowiedź będzie zależała od tego, jakie znaczenie przypisze się temu usprawiedliwieniu. Okoliczność, że krzywda jest skutkiem samoobrony, a więc że została zadana przez podmiot, który znajdował się w sytuacji zagrożenia, stanowi z pewnością jakąś rację za tym, że osoby niezaangażowane bezpośrednio w tego typu sytuację powinny zachować w tym względzie nieco większą powściągliwość. Nie sposób bowiem wykluczyć, iż mogłoby zdarzyć się tak, że w celu przeciwdziałania własnej krzywdzie wolno byłoby zrobić coś, co nie miałoby takiej samej wiarygodności moralnej - lub w ogóle nie byłoby uzasadnione - gdyby uczynione zostało w tym samym celu przez kogoś innego. W tego typu przypadkach usprawiedliwienie musi być jednak głębsze, gdyż na ogół 
zakłada się, że czynności polegające na stosowaniu opresyjnych środków (nawet pod adresem tych, którzy chcą wyrządzić nam szkodę) nie powinny być uprawomocnione na podstawie dość przypadkowych więzi, jakie mogą łączyć potencjalną ofiarę ze sprawcą jej krzywdy ale, przede wszystkim, na podstawie uznanych zasad czy wartości, co gwarantowałoby, że przyjście komuś w takiej sytuacji z pomocą nie budzi zastrzeżeń i jest moralnie dozwolone. Warunek ten spełnia bezosobowy z istoty rzeczy fakt, że każdemu przysługuje prawo do tego, aby nie być krzywdzonym bez uzasadnionego powodu i wbrew własnej woli. Tak więc gdy ktoś umyślnie stwarza zagrożenie dla jakiejś osoby - tj. gdy zgodnie z przyjętym przeze mnie poglądem inicjuje sekwencję zdarzeń, która do tego celu prowadzi - to można wówczas słusznie domniemywać, iż fakt ten w równym stopniu upoważnia do przeciwdziałania takiemu zachowaniu nie tylko tę osobę, lecz również osoby trzecie (Thompson, 2009, s. 99).

Rozważania te nie dowodzą, rzecz jasna, że tak szeroki charakter uprawnień do obrony przed krzywdą automatycznie przekłada się na znaczącą różnicę między jedną a drugą czynnością, niemniej jednak trudno byłoby zaprzeczyć, że w istotny sposób sprzyjają one twierdzeniu, iż brak takiej różnicy wymagałby wprowadzenia dość radykalnych ograniczeń co do możliwości udzielania pomocy tym, którzy są w ten sposób zagrożeni. A tego, jak myślę, nikt by sobie nie życzył. Choć można bowiem sensownie dyskutować, czy faktycznie mamy taki obowiązek, to jednak próba podważenia istniejących w tym zakresie praw szłaby za daleko, gdyż groziłaby zanikiem lub osłabieniem altruistycznych motywów i postaw, a to mogłoby prowadzić do dewastacji najbardziej cenionych z moralnego punktu widzenia zachowań oraz międzyosobowych więzi, które stanowią ważny czynnik w procesie kształtowania się grup oraz społeczeństw.

Szukając podstaw dla moralnego rozróżnienia między krzywdzeniem a przyzwalaniem na krzywdę, nie powinno się pomijać przeświadczenia, że w odniesieniu do przypadków paradygmatycznych może ono w pewien sposób wynikać również z różnicy, jaka istnieje między konstytuującymi je własnościami. Ponieważ przyzwolenie na krzywdę jest fizycznie możliwe tylko wtedy, gdy istnieje już sekwencja zdarzeń, która do tej krzywdy prowadzi, słuszne wydaje się w tej sytuacji przypuszczenie, iż ten rodzaj postępowania cechuje się również i tym, że osoba, która będzie przez tę sekwencję zdarzeń skrzywdzona na skutek tego, że czynność ta zostanie wykonana, będzie skrzywdzona dlatego, że straci coś (na przykład zdrowie 
lub życie), co jest dla niej jakimś dobrem, lecz co mogłaby mieć tylko dzięki sprawcy tej czynności (a mówiąc dokładnie - dzięki jego wysiłkowi będącemu skutkiem braku przyzwolenia na cudzą krzywdę). Własności tej nie posiada natomiast czynność krzywdzenia, z której wyizolowano czynniki zewnętrzne. W tym wypadku bowiem osoba skrzywdzona straci dobro, które cechuje między innymi to, że mogłoby ono do niej przynależeć niezależnie od sprawcy tej czynności. Na tej podstawie można dojść do wniosku, że jeśli ktoś przyzwala na czyjąś krzywdę, to tym samym odbiera tej osobie możliwość posiadania pewnego dobra, które mogłaby ona mieć tylko dzięki niemu; jeśli natomiast krzywdzi kogoś, to uniemożliwia swojej ofierze posiadanie dobra, które mogłaby mieć niezależnie od niego (Kamm, 1983, s. 301-302; 1992, s. 370). Ta odmienna, w gruncie rzeczy, relacja między sprawcą jednej i drugiej czynności a dobrem, jakie ktoś mógłby posiadać, powoduje, iż słuszne wydaje się twierdzenie, że dużo większe prawo do tego, by odebrać komuś możliwość dysponowania jakimś dobrem ma ten z nich, bez którego dobro to w ogóle nie mogłoby być przez tę osobę doświadczane, niż ten, którego postępowanie nie pełni dla nikogo tak istotnej roli. Nie ma w tym wnioskowaniu niczego, co byłoby niejasne, niezrozumiałe albo budziło uzasadniony sprzeciw. Skoro zakłada się, że mamy większe uprawnienia moralne do dysponowania tym, co istnieje wyłącznie dzięki nam, niż tym, czego istnienie jest od nas całkowicie niezależne, i co, w tym sensie, do nas nie należy, to powinno się z tego powodu domniemywać, że mamy również większe uprawnienia, aby decydować o tym, czy ktoś inny będzie posiadał dobra pierwszego rodzaju, aniżeli o tym, czy ma posiadać drugie $\mathrm{z}$ nich.

Choć pogląd ten uważam za słuszny w odniesieniu do paradygmatycznych przypadków krzywdzenia oraz przyzwalania na krzywdę, jakie zakłada Maszyna Tooleya, nie twierdzę przez to, że ma on również podobny stopień wiarygodności wszędzie tam, gdzie wobec tego typu przypadków obowiązują odmienne zasady kontrfaktyczności. Aby lepiej wyjaśnić moje stanowisko, nieco zrekonstruuję sposób funkcjonowania tego urządzenia i, z tego powodu, zmienię także okoliczności, w jakich znajdować się będą dzieci. W tym celu zakładam, że nawet kiedy jakaś osoba wciśnie guzik i zainicjuje tym samym sekwencję zdarzeń prowadzącą do krzywdy pierwszego dziecka, ma ona jeszcze możliwość zablokowania tego procesu i niedopuszczenia do tego, aby dziecko zostało faktycznie skrzywdzone. Taka sama możliwość istnieje również wówczas, kiedy osoba ta postanawia 
nie wcisnąć guzika - może ona w ciągu względnie krótkiego czasu zmienić swoją decyzję i w ten sposób nie pozwolić na to, aby jakaś obiektywnie istniejąca sekwencja zdarzeń doprowadziła do krzywdy drugiego dziecka. Przyjmuję również, że zapobieżenie czyjejś krzywdzie może dokonać się bezpośrednio, a nie tylko jako konsekwencja zmiany wcześniejszej decyzji o krzywdzeniu lub przyzwoleniu na krzywdę, a także, że między krzywdą pierwszego i drugiego dziecka nie zachodzi zależność polegająca na tym, że uchronienie przed szkodą jednego z nich zakłada koniecznie wyrządzenie szkody drugiemu.

Zgodnie z tym, co powiedziałem wcześniej, krzywda każdego dziecka polega na pozbawieniu go dobra, którym jest w tym wypadku jego zdrowie. Ponieważ sugerowałem, że mamy większe prawo do pozbawienia innych istot dóbr, które mogą posiadać tylko dzięki nam, niż tych, które mogą posiadać w sposób od nas niezależny, to z powodu wniosku, do którego sugestia ta nieuchronnie prowadzi - a mianowicie, że z obu czynności mniejszą ilość dobra zawiera w ostatecznym rozrachunku ta, do wykonania której mamy mniejsze prawo - niektórzy mogą dojść do wniosku, iż oznacza to, że zachowanie polegające na przyzwoleniu na krzywdę byłoby rzeczą moralnie lepszą nawet wtedy, gdyby miało miejsce dopiero po tym, jak zahamowaliśmy proces, który do niej prowadzi. Rozumowanie to oznaczałoby, że jeśli istnieją wystarczające racje, aby uważać, iż przyzwolenie na krzywdę jest moralnie lepsze od krzywdzenia w sytuacji

wstrzymania się od udzielenia pomocy: tj. wówczas, gdy jakaś osoba przyzwala na to, aby obiektywna sekwencja zdarzeń doprowadziła do czyjejś krzywdy,

to należałoby sądzić, że byłoby ono lepsze również w sytuacji

wycofania udzielonej wcześniej pomocy: tj. wówczas, gdy jakaś osoba najpierw skutecznie blokuje taką obiektywną sekwencję zdarzeń, lecz później usuwa przeszkodę wstrzymującą jej bieg, doprowadzając w ten sposób do czyjejś krzywdy.

To, co w decydujący sposób przemawia za tym, że tak właśnie jest, sprowadza się prawdopodobnie do przekonania, że przyzwolenie na krzywdę ma taką samą wartość moralną, gdy wstrzymujemy się od udzielenia pomocy, jak i wówczas, kiedy postanawiamy ją wycofać. Gdyby bowiem przyzwolenie na krzywdę różniło się w ten sposób od krzywdzenia w odniesieniu 
do jednej z przedstawionych sytuacji, to założenie - którym jest owo przekonanie - mówiące, iż ma ono zbliżoną wartość w obu z nich, umożliwia wniosek, że w podobnym zakresie różni się ono od krzywdzenia także w odniesieniu do sytuacji drugiej.

Nie wydaje się jednak, by tak faktycznie było. Żeby się o tym przekonać, porównajmy takie oto dwa przypadki:

1. Pewien człowiek, pozostający od jakiegoś czasu w szpitalu w stanie utraty świadomości, zapadł na chorobę, która prowadzi do jego kalectwa. Uchronić go przed tym może jedynie podłączenie na jakiś czas do innego żywego organizmu. Jest to bezpieczny zabieg, który nie powoduje żadnych przykrych konsekwencji dla zdrowej osoby. Adam, który pracuje w tym samym szpitalu, spełnia wszystkie potrzebne do tego celu warunki. Aby przeciwdziałać krzywdzie, musi on pójść na oddział, gdzie leży ten człowiek i spędzić tam kilka dni. Przez ten czas będzie podłączony do chorego, który na skutek tego odzyska świadomość i całkowicie wyzdrowieje. Adam nie postępuje jednak w ten sposób i nie użycza w tym celu swojego organizmu.

2. Marek, który również pracuje w tym szpitalu, spełnia w takim samym stopniu wszystkie wymagane warunki. Idzie on na oddział, gdzie leży chory i po rozmowie z personelem medycznym podejmuje decyzję o użyczeniu mu własnego organizmu. Na skutek tego zostaje połączony z jego organizmem. Gdy budzi się następnego dnia rano, zmienia jednakże zdanie, co powoduje, że lekarze są zmuszeni odłączyć go i przerwać terapię. W wyniku tego zostaje wznowiony proces chorobowy, który prowadzi nieuchronnie do okaleczenia pacjenta.

Różnica między jednym a drugim postępowaniem zakłada nie tylko odmienny charakter przyczynowości w odniesieniu do krzywdy, która powstanie z tego powodu, ale też odmienną sytuację, w jakiej znajdować się będzie chora osoba, kiedy swoje postępowanie wcieli w życie Adam oraz wówczas, gdy zrobi to Marek (Bennett, 1981, s. 89-92; Kagan, 1989, s. 107-111; Kamm, 1986, s. 310; McMahan, 1993, s. 258-262). Zachowanie polegające na wstrzymaniu się od udzielenia pomocy ma tę szczególną własność, że w żaden sposób nie przyczynia się do powstania sekwencji zdarzeń, która spowoduje krzywdę. Zgodnie z tym możemy powiedzieć, iż Adam nie jest w tym sensie odpowiedzialny przyczynowo za to, że osoba ta jest chora, a jeśli przyczyną jej krzywdy jest ta choroba, to słuszne wydaje się także twierdzenie, że nie jest on odpowiedzialny również za jej kalectwo. 
Postępowanie polegające z kolei na wycofaniu udzielonej wcześniej pomocy, choć nie inicjuje pierwotnie takiej sekwencji zdarzeń, przyczynia się jednak do tego (poprzez usunięcie przeszkody, która obecnie wstrzymuje jej bieg, a w dłuższym czasie spowoduje jej zanik), że będzie ona ponownie zapoczątkowana i kontynuowana także po tym, jak została zatrzymana i przestała funkcjonować. Wynika z tego, że to, co możemy powiedzieć o Marku, nie ma takiego samego znaczenia moralnego, jak to, co możemy powiedzieć o Adamie. Postępowanie Marka nie spowodowało, oczywiście, że osoba ta zachorowała, niemniej jednak w pewien sposób przyczyniło się do tego, że zostanie ona okaleczona - w taki mianowicie sposób, iż doprowadziło do wznowienia procesu chorobowego, który został wcześniej skutecznie zablokowany i który mógłby zostać raz na zawsze wyeliminowany, gdyby nie zrobił on tego, co faktycznie zrobił. W takich wypadkach inna jest również sytuacja osoby, która doświadcza krzywdy. To, co uczynił Adam, nie zmienia zasadniczo okoliczności, w których osoba ta znajdowała się dotychczas i w których znajduje się obecnie, gdy postępowanie to nie miało jeszcze miejsca. W każdym z tych interwałów czasu funkcjonuje sekwencja zdarzeń prowadząca do jej krzywdy, a osoba ta jest w taki sam sposób zagrożona kalectwem, jak wówczas, gdy wstrzymuje się on od udzielenia jej pomocy. Inaczej jest jednak, gdy pomoc zostaje wycofana. W momencie kiedy czyni to Marek, nie odbywa się żaden proces chorobowy, a osoba ta nie jest zagrożona. Jego postępowanie staje się przyczyną sprawczą tego, że w ruch zostaje wprawiona sekwencja zdarzeń, która doprowadzi do krzywdy. Choć Marek nie inicjuje tego procesu, jednak faktem jest, iż uruchamia go w sytuacji, w której nie miał on miejsca.

To wszystko powoduje, że skłaniam się ku poglądowi, iż mamy większe prawo, by decydować o tym, czy jakaś osoba będzie mogła cieszyć się dobrem (którego posiadanie zależy wyłącznie od nas), jeżeli nie zrobiliśmy niczego, co wstrzymałoby proces prowadzący do pozbawienia jej tego dobra, niż wówczas, gdy nie będzie ona narażona na jego utratę $\mathrm{z}$ tego powodu, że skutecznie powstrzymaliśmy jego bieg. Sądzę zatem, że gorszą rzeczą jest przyzwolenie na czyjąś krzywdę - i tym samym pozbawienie tej osoby pewnego dobra - w sytuacji, gdy wycofujemy się z udzielonej wcześniej pomocy, tj. wtedy, kiedy wymaga to uruchomienia sekwencji zdarzeń, która by do tego doprowadziła, niż wówczas, gdy wstrzymujemy się od jej udzielenia, tj. kiedy funkcjonująca już sekwencja zdarzeń, na powstanie której nie mieliśmy żadnego wpływu, doprowadzi do podobnego skutku 
w okolicznościach, w których moglibyśmy skutecznie temu zapobiec. Czy uwagi te mogą mieć jakieś negatywne konsekwencje dla bronionego przeze mnie poglądu o moralnej różnicy między paradygmatycznymi przypadkami krzywdzenia oraz przyzwolenia na krzywdę? Nie wydaje mi się, aby tak było. Jestem również przekonany, że uzasadnienie tej różnicy na podstawie tezy dotyczącej posiadania większych uprawnień moralnych w stosunku do dóbr, które zależą wyłącznie od nas - zarówno w tym sensie, że istnieją dzięki nam, jak również, że tylko dzięki nam może je ktokolwiek posiadać - nadal utrzymuje swoją moc.

\section{Bibliografia}

Benatar, D. (2009). Better Never to Have Been. The Harm of Coming into Existence. New York: Clarendon Press.

Bennett, J. (1981). Morality and Consequences. W: S. McMurrin (red.), The Tanner Lectures on Human Values (s. 47-116). T. 2. Salt Lake City: University of Utah Press.

Cohen, C.B. (1997). The Morality of Knowingly Conceiving Children With Serious Conditions: An Expanded „Wrongful Life” Standard”. W: N. Fotion, J.C. Heller (red.), Contingent Future Persons. On the Ethics of Deciding Who Will Live, or Not, in the Future (s. 27-40). Dordrecht: Kluwer Academic Publishers.

Davis, N. (1984). Abortion and Self-Defense. Philosophy \& Public Affairs, 13, s. $175-207$.

Feinberg, J. (1987). Harm to Others. New York: Oxford University Press.

Feinberg, J. (1992). Wrongful Life and the Counterfactual Element in Harming. W: J. Feinberg, Freedom and Fulfilment (s. 3-37). Princeton: Princeton University Press.

Harman, E. (2009). Harming as Causing Harm. W: M.A. Roberts, D.T. Wasserman (red.), Harming Future Persons. Ethics, Genetics and the Nonidentity Problem (s. 137-155). Dordrecht: Springer.

Harris, J. (1992). The Wrong of Wrongful Life. W: J. Harris, In Wonderwoman and Superman: The Ethics of Human Biotechnology. Oxford: Oxford University Press.

Kagan, S. (1989). The Limits of Morality. Oxford: Oxford University Press.

Kamm, F.M. (1983). Killing and Letting Die: Methodological and Substantive Issues. Pacific Philosophical Quarterly, 64, 297-312. 
Kamm, F.M. (1986). Harming, Not Aiding, and Positive Rights. Philosophy and Public Affairs, 15, 3-32.

Kamm, F.M. (1992). Non-Consequentialism, the Person as End -To-Itself, and the Significance of Status. Philosophy and Public Affairs, 21, 354-389.

Kamm, F. (1996). Morality, Mortality. T. 2: Rights, Duties, and Status. New York: Oxford University Press.

Kamm, F. (2007). Intricate Ethics. New York: Oxford University Press.

McMahan, J. (1993). Killing, Letting Die, and Withdrawing Aid. Ethics, 103, 250-279.

McMahan, J. (2012). Etyka zabijania. Warszawa: Wydawnictwo Naukowe PWN.

Montague, P. (1981). Self-defence and Choosing among Lives. Philosophical Studies, 40, 207-219.

Morreim, E.H. (1988). The Concept of Harm Reconceived. Law and Philosophy, 7, 3-33.

Parfit, D. (2012). Racje i osoby. Warszawa: Wydawnictwo Naukowe PWN.

Różyńska, J. (2013). Złe geny, „złe życia” i koncepcja krzywdy progowej. Etyka, $47,50-66$.

Rutkowski, M. (2017). Granice etyki. Warszawa: Wydawnictwo Naukowe Semper.

Steinbock, B. (2009). Wrongful Life and Procreative Decisions. W: M.A. Roberts, D.T. Wasserman (red.), Harming Future Persons. Ethics, Genetics and the Nonidentity Problem (s. 155-179). Dordrecht: Springer.

Thomson, J.J. (2009). Obrona własna. W: T. Żuradzki, T. Kuniński (red.), Etyka wojny. Antologia tekstów (s. 76-101). Warszawa: Wydawnictwo Naukowe PWN.

\section{HURTING AND ALLOWING HARM. PART II: A RIGHT TO SELF DEFENSE}

\section{Summary}

In this article I defence the thesis that there is a morally significant difference between doing harm (or harming) and merely allowing harm to happen. 